\title{
GOSPODAROWANIE KAPITAŁEM LUDZKIM W JEDNOSTKACH SAMORZĄDU TERYTORIALNEGO
}

\section{WSTĘP}

Kapitał ludzki jest uznawany za ważny czynnik, który ma decydujący wpływ na pracę jednostek samorządu terytorialnego, których sprawność działania zależy od zatrudnionych pracowników. Na poziomie samorządu terytorialnego, stosownie do jego roli w systemie władzy publicznej, zjawiskiem naturalnym jest szerokie zainteresowanie mieszkańców realizacją zadań bieżących i rozwojowych przez daną jednostkę samorządu terytorialnego. Jednak często spotykamy się z tym, iż sugestie mieszkańców są pomijane przez rządzących. W dłuższej perspektywie prowadzi to do konfliktów i do niezadowolenia społeczeństwa, które posiada ogromny potencjał rozwojowy.

Sprawne zarządzanie w dużej mierzę zależy od efektywnego wykorzystania istniejącego w urzędzie potencjału ludzkiego. Do realizacji zamierzonych celów potrzebna jest odpowiednio dobrana kadra pracowników, a więc kompetentnych i dobrze współpracujących ze sobą zespołów ludzkich. Zatem ważne jest zapewnienie w urzędzie niezbędnego personelu w wymiarze ilościowym i jakościowym, z wykorzystaniem go zgodnie z misją i celem jednostki samorządu terytorialnego. Niezbędna jest odpowiednia procedura rekrutacji personelu, systemu ocen i awansowania pracowników oraz możliwość zapewnienia szkoleń w celu zwiększenia poziomu kwalifikacji pracowników.

W jednostce samorządu terytorialnego kapitał ludzki jest rozumiany jako zespół kompetencji wszystkich zatrudnionych pracowników wraz z ich postawami i wartościami, które składają się na kulturę organizacyjną. Wiedza, kwalifikacje i postawy pracowników decydują bowiem o różnicach zarządzania pomiędzy poszczególnymi

* Doktorantka, Katedra Gospodarki Samorządu Terytorialnego, Wydział Ekonomiczno-Socjologiczny, Uniwersytet Łódzki. 
jednostkami samorządu terytorialnego. Kapitał ludzki to nie tylko liczba pracowników w urzędzie, lecz posiadane przez nich zdolności, umiejętności i gotowość do dzielenia się posiadaną wiedzą, jak i chęć pogłębiania swojej wiedzy na różnego rodzaju szkoleniach.

Ze względu na częste pomijanie znaczenia kapitału ludzkiego dla rozwoju społecznego celem artykułu staje się przybliżenie problematyki związanej z gospodarowaniem kapitałem ludzkim w jednostkach samorządu terytorialnego. W początkowym fragmencie opracowania przybliżono zagadnienie kapitału ludzkiego. Zasadnicza część artykułu poświęcona jest kierowaniu i doskonaleniu kapitału ludzkiego w jednostkach samorządu terytorialnego.

\section{POJĘCIE KAPITAŁU LUDZKIEGO}

Kapitał ludzki w literaturze przedmiotu definiuje się na różnorakie sposoby, a wynika to głównie z obszaru badań, zainteresowań oraz przytaczanych przykładów. Nie jest możliwe wskazanie definicji tego pojęcia w sposób jednoznaczny, ponieważ jedni autorzy mówią o życiu człowieka jako kapitale, inni wskazują na kapitał ucieleśniony w człowieku, a jeszcze inni mówią o zasobie kapitału, jaki stanowią ludzie wraz z ich wiedzą, umiejętnościami i zdrowiem. Inwestowanie w kształcenie i rozwój kwalifikacji pracowników stało się istotnym elementem od przełomu lat osiemdziesiątych i dziewięćdziesiątych XX wieku, gdy nastąpiły zmiany ustrojowe. Kapitał ludzki w dzisiejszych czasach charakteryzuje się dynamicznym wzrostem znaczenia wiedzy na wszystkich szczeblach życia społeczno-gospodarczego, co podkreśla, iż człowiek jest wartościowym elementem w zasobach organizacji ${ }^{1}$.

Autorka artykułu za najbardziej trafne i odpowiednie do danego tematu przyjęła poglądy reprezentowane przez polskich ekonomistów. Według R.S. Domańskiego, kapitał ludzki to „zasób wiedzy, umiejętności, zdrowia, energii witalnej zawartej w społeczeństwie. Zasób ten jest dany przez genetyczne cechy danej populacji raz na zawsze, ale można go powiększać drogą inwestycji, zwanych inwestycjami w człowieka: w ludzi, w kapitał ludzki, w ludzkie życie"2.

Natomiast według J. Grodzickiego, poprzez kapitał ludzki należy rozumieć „zasób wiedzy i umiejętności o określonej wartości, będący źródłem przyszłych zarobków czy satysfakcji, przy czym jest on odnawialnym i stale powiększanym potencjałem ludzkim"3. W tej definicji kapitału ludzkiego zawarty jest wymiar rynkowy (odnosi się

1 G. Łukasiewicz, Kapitał ludzki organizacji. Pomiar i sprawozdawczość, Wydawnictwo Naukowe PWN, Warszawa 2009, s. 23.

2 R.S. Domański, Kapitał ludzki i wzrost gospodarczy, Wydawnictwo Naukowe PWN, Warszawa 1993, s. 19.

3 J. Grodzki, Rola kapitału ludzkiego w rozwoju gospodarki globalnej, Wydawnictwo Uniwersytetu Gdańskiego, Gdańsk 2003, s. 46. 
do zasobów wiedzy, umiejętności, zdolności, kwalifikacji, postaw oraz zdrowia, które jednostka zamierza wykorzystywać bądź już wykorzystuje w swojej pracy) i wymiar osobisty (obejmuje zasoby wymiaru rynkowego, które osoba wykorzystuje w życiu osobistym poprzez rozwój zainteresowań, a wiedza i umiejętności nabyte w ten sposób nie będą miały przełożenia na wzrost wydajności ich pracy) ${ }^{4}$.

Dokonując przeglądu innych definicji kapitału ludzkiego warto wskazać na pogląd reprezentowany przez A. Sadowskiego, który uważa, że „w zasobach ludzkich skumulowany jest przede wszystkim kapitał ludzki, społeczny i kulturowy"5. Kapitał ludzki obejmuje wiedzę, umiejętności zawodowe, stan zdrowia, znajomość języków obcych, znajomość obsługi komputerów, gotowość do kontaktów i związaną z tym elastyczność względem różnych kultur oraz stylów życia. Elementami kapitału ludzkiego są również aspiracje, ambicje i chęć rozwoju ze strony mieszkańców, co pozwala tworzyć odpowiednie ścieżki karier. Kapitał społeczny jest spoiwem społeczeństwa, ponieważ wypełnia przestrzeń pomiędzy ludźmi. Prowadzi do wzrostu skuteczności funkcjonowania i rozwoju organizacji poprzez właściwe współdziałanie pomiędzy mieszkańcami. Natomiast kapitał kulturowy składa się z pewnych znaczeń, które posiadają jednostki czy też zbiorowości, które łączą się z instytucjami społeczeństwa demokratycznego, mechanizmu rynkowego, co w konsekwencji prowadzi do prawidłowego realizowania interesów społecznych ${ }^{6}$. Według S. Walukiewicza, kapitał ludzki obejmuje „wszystkie, ale to absolutnie wszystkie, zasoby niematerialne (przymioty) kojarzone z człowiekiem traktowanym jako samodzielna istota ludzka"7. Dla wyjaśnienia istoty kapitału ludzkiego, posłużył się pięcioma obrazowymi przykładami:

- kapitałem ludzkim rozważanej osoby są jej szeroko rozumiane kompetencje i doświadczenie;

- szeroko rozumiane wiedza i zdolności są bardzo istotną składową (częścią) kapitału ludzkiego danej osoby. Wiedzę dzieli się na wiedzę skodyfikowaną (zawartą) w powszechnie dostępnych książkach, bibliotekach, bazach danych, archiwach itp. oraz na wiedzę spersonalizowaną, którą posiada dana osoba lub stosunkowo wąski krąg osób. Z wiedzą spersonalizowaną silnie związane jest pojęcie zdolności i talentu (fenomenalna pamięć, absolutny słuch, atrakcyjny wygląd, zdolności artystyczne, aktorskie, przywódcze itp.);

- w niektórych zawodach bardzo ważną składową kapitału ludzkiego jest zdrowie i wydolność organizmu danej osoby;

4 G. Łukasiewicz, Kapitał ludzki organizacji..., s. 20-21.

5 A. Sadowski, Kapitał społeczny i kulturowy heterogenicznej „metropolii” wschodniego pogranicza, [w:] Jałowiecki B., Majer A., Szczepański M.S. (red.), Przemiany miasta. Wokół socjologii Aleksandra Wallisa, Wydawnictwo Naukowe Scholar, Warszawa 2005, s. 258.

6 Ibidem, s. 258-260.

7 S. Walukiewicz, Kapitał ludzki. Skrypt akademicki, Instytut Badań Systemowych Polskiej Akademii Nauk, Warszawa 2010, s. 25.

8 Ibidem, s. 25-26. 
- jest jeszcze stosunkowo liczna i różnorodna grupa elementów (składowych) kapitału ludzkiego, którą określimy zbiorczym terminem jako nastawienie życiowe do świata jako takiego. Są w tej grupie zarówno elementy pozytywne (optymizm, otwartość, prawdomówność), jak negatywne (pesymizm, skrytość, hipokryzja);

- z nastawienia życiowego należy wydzielić te elementy kapitału ludzkiego, które są bardzo ważne z punktu widzenia kapitału społecznego danej grupy/zespołu. Są wśród nich takie składowe jak: zaufanie, tolerancja, lojalność, czyli elementy pozytywne nastawienia życiowego, jak i negatywne - takie jak podejrzliwość, kłótliwość, nielojalność.

Warto również zwrócić uwagę, że kapitał ludzki ma wpływ na rozwój społeczeństw, narodów, a nawet ludzkości. W szczególności podkreśla się, że kapitał ludzki:

- wpływa na innowacyjność gospodarek i społeczeństw, ich zdolności absorpcyjne w zakresie przyswajania i wdrażania światowych osiągnięć naukowych, technicznych, organizacyjnych, mentalnościowych;

- wpływa na przemiany instytucjonalne i unowocześnienie struktury różnego rodzaju;

- sprzyja propagowaniu i upowszechnianiu nowoczesnych wzorców konsumpcji i jakości życia;

- kształtuje nowoczesną infrastrukturę techniczno-organizacyjną, informatyczną oraz socjalną.

Z przedstawionych definicji wynika, że wykorzystanie kapitału można rozpatrywać na poziomie społeczeństwa, organizacji i jednostki. Wobec tego prawidłowe kierowanie kapitałem ludzkim w jednostkach samorządu terytorialnego pozwala wywołać pozytywne zmiany w organizacji.

\section{KIEROWANIE KAPITAŁEM LUDZKIM W JEDNOSTKACH SAMORZĄDU TERYTORIALNEGO}

Na kierowanie kapitałem ludzkim w organizacji ma wpływ odpowiednie zaangażowanie i kreatywność wszystkich pracowników, a w szczególności kierowników. W przypadku jednostek samorządu terytorialnego, duże znaczenie ma sam lider (organ wykonawczy), czyli miejscowy przywódca społeczny, który pobudza do działania, określa wzorce postępowania i stawia wymagania. To osoba, która z uporem dąży do celu, a jednocześnie pociąga za sobą innych, aby prawidłowo funkcjonował urząd. Kierowanie daną jednostką terytorialną to praca zbiorowa, a wartość organu wykonawczego zależy od pracy innych. Warto więc posiadać wykwalifikowany personel, dzięki któremu organ wykonawczy może korzystać z usług ludzi mądrych, znających

9 H. Król, A. Ludwiczyński (red.), Zarządzanie zasobami ludzkimi. Tworzenie kapitału ludzkiego organizacji, Wydawnictwo Naukowe PWN, Warszawa 2006, s. 111. 
problemy otoczenia, mających pomysł, czyli specjalistów z różnych dziedzin ${ }^{10}$. Warto zwrócić uwagę, że rządzenie jednostką samorządu terytorialnego to inaczej rządzenie dla innych (mieszkańców). Zatem od kierownika urzędu i poszczególnych pracowników zależy, czy zmiany będą korzystne czy też nie.

Lider to osoba, która koordynuje prace podległych mu osób, aby wspólnie uzyskać założone cele. Jego zadaniem jest prawidłowe zarządzanie zespołem, który realizuje zadania. Podejmuje on również różnorakie decyzje, a jego działania muszą być sprawne i skuteczne. Od tego, jak przebiega jego współpraca z pracownikami zależy skuteczność realizacji celów organizacji i zaspokajanie przez nią potrzeb społecznych. Jeśli jednak organ wykonawczy jest niekompetentny, organizacja nie zdoła zrealizować zamierzonych celów ${ }^{11}$.

Kierownik urzędu stanowi ważny kanał komunikacji wewnętrznej i zewnętrznej, ponieważ pracuje z ludźmi i przez ludzi, ale i z innymi kierownikami. Zarządza organizacją jako całością lub częścią, odpowiedzialny jest również za kształtowanie i koordynowanie pracy innych. Musi również podejmować skomplikowane decyzje, a więc oczekuje się od niego radzenia sobie w trudnych sytuacjach. Jest to osoba, dzięki której organizacja może uzyskać pożądane efekty dla dobra społeczności ${ }^{12}$. Zatem każdy lider musi posiadać wizję przyszłości, jakiej pragnie dla siebie i swojego otoczenia. Organ wykonawczy musi tak współpracować z pracownikami, aby wyzwolić ich inwencję i zmotywować do osiągnięcia sukcesu oraz uzyskać z ich strony pełne zaangażowanie w realizacji wspólnego celu.

Pracownicy urzędu oczekują, że ich kierownik będzie posiadał fachową wiedzę, a jego doświadczenie pomoże w realizacji prawidłowej komunikacji i reagowania na potrzeby i problemy pracowników. Zwróćmy uwagę, że pracownicy nie lubią, gdy przełożony nigdy nie jest dostępny lub znika przy pierwszych nadarzających się problemach w organizacji. Dlatego też najbardziej cenioną cechą zachowania przełożonego jest konsekwencja ${ }^{13}$, a nieoceniona jest umiejętność budowania zgranego zespołu i zdolność kierowania nim, aby stanowił źródło konkurencyjności dla pozostałych jednostek.

Zmotywowani pracownicy są w stanie wiele osiągnąć i zwiększyć szanse rozwoju własnego obszaru, dlatego też odpowiednie procesy zarządzania kapitałem ludzkim powinny stać się istotnym elementem w administracji publicznej. Aktywny udział organu wykonawczego w podejmowaniu decyzji wynika z tego, iż jest on odpowiedzialny za zarządzanie procesami pracy w danej organizacji. Jednak dość często brakuje liderów, którzy w szczególny sposób potrafią wpłynąć na swoich pracowników. Mieszkańcy

10 E. Wojciechowski, Gospodarka samorządu terytorialnego, Difin, Warszawa 2012, s. 46.

11 J. Dubiel (red.), Gospodarowanie kapitałem Iudzkim w organizacji. W kierunku poprawy efektywności pracy, Wydawnictwo Uniwersytetu Rzeszowskiego, Rzeszów 2014, s. 50.

12 Ibidem, s. 50-51.

13 J. Fitzenz, Rentowność inwestycji w kapitał ludzki, Oficyna Ekonomiczna: Dom Wydawniczy ABC, Kraków 2001, s. 238. 
w trakcie wyborów powinni zadbać o wybór odpowiedniej osoby, która będzie ich reprezentować, ponieważ ich rola w jednostkach jest obecnie najważniejsza.

Każda organizacja dysponuje konkretnymi zasobami, lecz szczególną rolę odgrywają zasoby ludzkie, a więc zintegrowana zbiorowość pracowników. Za pracę ludzi i ich wysiłek odpowiada kierownik, który świadomie inwestuje w szkolenia, edukacje i rozwój osobowości swoich pracowników.

\section{DOSKONALENIE KAPITAŁU LUDZKIEGO W JEDNOSTKACH SAMORZĄDU TERYTORIALNEGO}

Działanie według wytycznych z ustawy oraz regulaminów nie zapewni sprawności działania urzędu, dlatego konieczne jest posiadanie odpowiedniego personelu, który chcę wdrożyć w życie obowiązujące przepisy, a jednocześnie dąży do zwiększenia efektywności zatrudnionych w nim ludzi. Współczesne zmiany zachodzące w gospodarce traktują pracowników jako zasób strategiczny, ponieważ ich kwalifikacje i zaangażowanie w poszczególne sprawy istotne dla społeczeństwa, stają się podstawowym czynnikiem przewagi konkurencyjne, chociażby dla jednostek sąsiadujących. Pracownicy powinni posiadać umiejętności personalne (łatwość radzenia sobie ze stresem i twórcze rozwiązywanie problemów) oraz interpersonalne (motywowanie innych, zdobywanie władzy i wpływu). Umiejętności te bez wątpienia wpływają na kształtowanie kapitału ludzkiego jako zasobu strategicznego ${ }^{14}$. W tym ujęciu kapitał ludzki traktować można jako najcenniejsze aktywa urzędu, a więc zbiór wiedzy, umiejętności, doświadczeń, motywacji, kompetencji, odpowiedzialności, jak również zdolności rozwiązywania nadarzających się problemów.

Zarządzanie zasobami ludzkimi to strategiczne i spójne podejście do zarządzania najbardziej wartościowymi aktywami organizacji, mianowicie pracującymi w niej ludźmi, którzy mają istotny wpływ na realizacje jej celów ${ }^{15}$. Zarządzanie organizacją w zakresie rozwoju zasobów ludzkich powinno być zgodne z interesami i wymaganiami społeczeństwa. Celem nauki w obrębie organizacji jest zwiększenie jej szans i możliwości. Jest to zgodne z podstawowymi zasadami zarządzania zasobami ludzkimi, czyli koniecznością inwestowania w ludzi, aby rozwijać kapitał ludzki potrzebny w organizacji i zwiększyć zasób wiedzy i umiejętności. Teoria kapitału ludzkiego zaznacza bowiem, iż wiedza i umiejętności pracowników uzyskane w trakcie nauki, szkoleń i doświadczeń, stwarzają zapas kapitału produkcyjnego ${ }^{16}$.

14 T. Sikorska (red.), Perspektywy kapitału ludzkiego jako czynnika wzrostu gospodarczego Polski, Wydawnictwo Politechnika Warszawska, Warszawa 2002, s. 25.

15 M. Armstrong, Zarządzanie zasobami ludzkimi, Oficyna Ekonomiczna: Dom Wydawniczy ABC, Kraków 2000, s. 19.

16 Ibidem, s. 431. 
Zasoby ludzkie można określić jako zbiorowość pracowników tworzącą system, który może być określany w następujących aspektach ${ }^{17}$ :

- organizacyjnym (zespoły i grupy stanowisk pracy, wyróżnione w ramach struktury organizacyjnej przedsiębiorstwa),

- ergonomicznym (poszczególne typy układu człowiek - maszyna lub człowiek - praca),

- psychologicznym (zbiór indywidualnych zachowań ludzkich),

- społeczno-ekonomicznym (odwzorowanie środowiska zawodowego, występującego jako siła robocza na rynku pracy),

- prawnym (ogół podmiotów, będących stroną w stosunku pracy).

Podstawową wartością dla doskonalenia kapitału ludzkiego w organizacji jest rozwój pracowników, co w konsekwencji może przynosić korzyści zarówno dla organizacji, jak i dla samych zatrudnionych w niej pracowników. Rozwój zespołu obejmuje wszystkie działania, które wspierają proces doskonalenia kwalifikacji i podnoszenia wiedzy pracowników. Obecnie dla zatrudnionych nie jest tak ważne wynagrodzenie, jak możliwość rozwoju indywidualnego, w tym również awansu ${ }^{18}$.

Ważnym elementem kapitału jest więc, podnoszenie kwalifikacji pracowników, ponieważ jest to dobre dla organizacji, jak i ich samych (należy zabiegać o stworzenie organizacji uczącej się). Pracownicy oczekują, że będą mieli możliwość podnoszenia swoich kwalifikacji, co podniesie poziom ich umiejętności. Uważają również, że szkolenia usprawnią im prace i poprawią jej wyniki, co skutkuje tym, iż dany pracownik wniesie większy wkład w wyniki całej organizacji. Można wymienić trzy czynniki, dla których rozwój kwalifikacji ma tak duże znaczenie dla personelu. Po pierwsze umożliwia zwiększenie zarobków, po drugie wzrasta satysfakcja z pracy, a po trzecie zwiększa wkład w osiągnięcia organizacji ${ }^{19}$.

Warto zwrócić uwagę, że w dzisiejszych czasach dość powszechne jest przekonanie, że wiedza to element konieczny do jakichkolwiek zmian i zdobywania nowych możliwości. Warto więc konkurować o kapitał ludzki, gdyż ma on często większą wartość niż budynki, maszyny czy chociażby udziały finansowe. Wiedza podnosi poziom pracy, ponieważ jest to zbiór doświadczeń, koncepcji, przekonań i informacji, które mogą odpowiednio wpływać na rozwój organizacji. Pomaga ona zauważyć i zrozumieć zachodzące zmiany w otoczeniu, co pozwala wyciągać wnioski i dostosowywać działania do jego potrzeb i wyzwań20.

17 A. Stabryła, Podstawy zarządzania firmą. Modele, metody, praktyka, Antykwa, KrakówKluczbork 1997, s. 179.

18 J. Dubiel (red.), Gospodarowanie kapitałem..., s. 119.

19 J. Fitz-enz, Rentowność inwestycji..., s. 238.

20 J. Penc, Menedżerowie i organizacje jutra. Praktyka kierowania w społeczeństwie wiedzy, Wydawnictwo Wyższej Szkoły Policji w Szczytnie, Szczytno 2010, s. 18. 


\section{PODSUMOWANIE}

Rozpoczęcie artykułu rozważaniami na temat kapitału ludzkiego i przedstawienie wybranych definicji było zasadne, ponieważ jego celem było zwrócenie uwagi na kwestie, które nie zawsze są brane pod uwagę. Często pomija się znaczenie kapitału ludzkiego dla rozwoju społecznego, a większą uwagę zwraca się na rozwój ekonomiczny, wzrost gospodarczy, jak również zwiększenie produkcji. Jednocześnie zanika chęć współpracy, a społeczność odnosi się do siebie z nieufnością i brakiem jakiejkolwiek integracji dla dobra wspólnoty, co ma decydujący wpływ na jakość życia człowieka w jednostce samorządu terytorialnego. Gospodarowanie kapitałem ludzkim w organizacji uznawane jest za ważny czynnik, który ma decydujący wpływ na jej sukces poprzez odpowiednią jakość zasobów ludzkich (wiedzy, kwalifikacji, motywacji).

Zakres zadań, jakie ustawodawca przekazał samorządom wymaga od pracowników wysokich kwalifikacji, co w konsekwencji powoduje wśród nich konkurencje, co skutkuje ciągłym rozwojem i utrzymaniem rzetelnych pracowników na stanowiskach pracy. Społeczeństwo postrzega samorząd terytorialny nie tylko w kategoriach organizacji realizującej zadania, ale także jako organizację, która służy otoczeniu w którym funkcjonuje. Skutkuje to większym naciskiem na etyczne postawy działania poszczególnych pracowników, ponieważ efektywny personel jest w stanie zapewnić wysoką jakość usług, co w przypadku jednostek samorządu terytorialnego, powoduje zadowolenie wśród mieszkańców. Warto zwrócić uwagę, że kluczowym celem jednostek samorządu terytorialnego jest zaspokajanie potrzeb coraz to większej liczby obywateli.

Pracownicy z odpowiednią wiedzą, kwalifikacjami, twórczością oraz wytrwałością to obecnie kluczowy czynnik sukcesu organizacji. Sposób, w jaki urzędnik wykonuje swoją prace w jednostce samorządu terytorialnego stanowi ważny element kształtowania opinii i wizerunku organizacji. Ważny jest również lider, który ze względu na dobrą znajomość lokalnych problemów realizuje zadania zgodnie z potrzebami mieszkańców, a taka postawa w oczach społeczeństwa jest zdecydowanie godna pochwały. Jednak efektywność całego zespołu (organ wykonawczy oraz pracownicy urzędu) zależy w dużym stopniu od tego, jakie relacje panują między nimi (wspólne formułowanie zadań, następnie ich wykonanie, jak również ocena i docenianie wkładu poszczególnych osób w osiągnięciu założonego celu). Elementy te coraz częściej stanowią podstawę profesjonalnego działania organizacji, wśród których wiedza odgrywa coraz większą rolę.

\section{BIBLIOGRAFIA}

Armstrong M., Zarządzanie zasobami ludzkimi, Oficyna Ekonomiczna: Dom Wydawniczy ABC, Kraków 2000.

Domański R.S., Kapitał ludzki i wzrost gospodarczy, Wydawnictwo Naukowe PWN, Warszawa 1993. 
Dubiel J. (red.), Gospodarowanie kapitałem Iudzkim w organizacji. W kierunku poprawy efektywności pracy, Wydawnictwo Uniwersytetu Rzeszowskiego, Rzeszów 2014.

Fitzenz J., Rentowność inwestycji w kapitał ludzki, Oficyna Ekonomiczna: Dom Wydawniczy ABC, Kraków 2001.

Grodzki J., Rola kapitału ludzkiego w rozwoju gospodarki globalnej, Wydawnictwo Uniwersytetu Gdańskiego, Gdańsk 2003.

Jałowiecki B., Majer A., Szczepański M.S. (red.), Przemiany miasta. Wokół socjologii Aleksandra Wallisa, Wydawnictwo Naukowe Scholar, Warszawa 2005.

Król H., Ludwiczyński A. (red.), Zarządzanie zasobami ludzkimi. Tworzenie kapitału ludzkiego organizacji, Wydawnictwo Naukowe PWN, Warszawa 2006.

Łukasiewicz G., Kapitał ludzki organizacji. Pomiar i sprawozdawczość, Wydawnictwo Naukowe PWN, Warszawa 2009.

Penc J., Menedżerowie i organizacje jutra. Praktyka kierowania w społeczeństwie wiedzy, Wydawnictwo Wyższej Szkoły Policji w Szczytnie, Szczytno 2010.

Sikorska T. (red.), Perspektywy kapitału ludzkiego jako czynnika wzrostu gospodarczego Polski, Wydawnictwo Politechnika Warszawska, Warszawa 2002.

Stabryła A., Podstawy zarządzania firmą. Modele, metody, praktyka, Antykwa, Kraków-Kluczbork 1997.

Walukiewicz S., Kapitał ludzki. Skrypt akademicki, Instytut Badań Systemowych Polskiej Akademii Nauk, Warszawa 2010.

Wojciechowski E., Gospodarka samorządu terytorialnego, Difin, Warszawa 2012. 